pulmonale. A further group of scores includes appetite, weight loss, exercise tolerance, and attitude to the disease. Hepatic fibrosis or portal hypertension were not included in the scoring system, perhaps because of their relative rarity, though severe hepatic disease undoubtedly influences the outlook in some cases.

It is not clear whether this system has advantages over previous ones, particularly since it relies heavily on pulmonary function tests, which are not easy to perform accurately in young children. Moreover, some criteria such as changes in chest radiographs and physical examination of the chest are difficult to standardize, while a certain diagnosis of cor pulmonale in its early stages is difficult to make in cystic fibrosis. ${ }^{11}{ }^{12}$ There is not yet, nor is there likely to be, a completely satisfactory prognostic scoring system for cystic fibrosis, particularly since the disease is peculiarly subject to unexpected fluctuations in its course. Consequently, though a physician will be helped by his own attempts to evaluate his cases in a standardized manner, he cannot usually give a precise prognosis in terms of months or years. Patient and parents are unlikely to be helped by being offered a numerical score instead of hope. ${ }^{13}$

\footnotetext{
1 Danks, D. M., Allan, J., and Anderson, C. M., Annals of Human Genetics, $1965,28,323$

Pugh, R. J., and Pickup, J. D., Archives of Disease in Childhood, 1967, 42, 544.

3 Carter, C. O., and Watson, G. I., in Modern Problems in Paediatrics, Vol. 10, p. 187. Basel and New York, S. Karger, 1967.

+ Kramer, E. R., Crane, M. M., Sirken, M. G., and Brown, M. L., American fournal of Public Health, 1962, 52, 2041.

Fanconi, G., Uehlinger, E., and Knauer, C., Wiener medizinische Wochenschrift, 1936, 86, 753.

( Andersen, D. H., American fournal of Diseases in Children, 1938, 56, 344 Shwachman, H., and Kulczycki, L. L., American fournal of Diseases in Children, 1958, 96, 6 .

Doershuk, C. M., et al., fournal of Pediatrics, 1964, 65, 677.

9 Cooperman, E. M., Park, M., McKee, J., Assad, J. P., Canadian Medical Association fournal, 1971, 105, 588 .

10 Taussig, L. M., Kattwinkel, J., Friedewald, W. T., and di Sant'Agnese, Taussig, L. M., Kattwinkel, J., Friedewald,

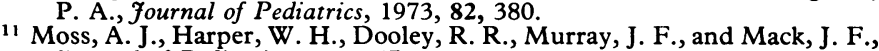
fournal of Pediatrics, 1965, 67, 797.

12 Moss, A. J., in Modern Problems in Pediatrics, Vol. 10, p. 189. Basel and New York, S. Karger, 1967.

13 Matthews, L. W., Fournal of Pediatrics, 1973, 82, 389.
}

\section{Single-dose Treatment of Gonorrhoea}

Many patients suffering from gonorrhoea fail to come back to a venereal disease clinic after their first visit. This immediate default rate may be as high as $30 \% .{ }^{1}$ If treatment has not been completed, some patients may believe themselves cured while still harbouring gonococci. Though relapse is usually obvious in men, symptoms of uncomplicated gonorrhoea are often minimal in women. To lessen the risks from default many venereologists prefer to give treatment in a single dose.

The treatment of gonorrhoea has recently been reviewed by S. K. Sim. ${ }^{2}$ Penicillin has for many years been the favoured antibiotic because of its effectiveness and lack of toxicity. The emergence of strains of gonococci which are relatively insensitive to it has necessitated the use of larger doses of up to 2.4 to 4.8 megaunits, but these have the painful disadvantage to the patient of a large volume of injected material. About $30 \%$ of strains of gonococci now isolated in London need concentrations of $0.125 \mu \mathrm{g}$ penicillin per $\mathrm{ml}$ or more for their inhibition in vitro, and such strains often show diminished sensitivity to other antibiotics. Slowrelease of oral penicillin preparations should not be used to treat gonorrhoea, but good results have been obtained with a single dose of 1.2 megaunits of procaine penicillin if it is given in conjunction with $2 \mathrm{~g}$ probenecid to enhance the blood level by delaying excretion. P. Rodin and A. Seth ${ }^{3}$ had only two failures in 105 men so treated. R. J. C. Cobbold and his colleagues, ${ }^{4}$ who treated 264 men with the same dose of penicillin but with $1 \mathrm{~g}$ probenecid, had 11 failures within one week of treatment. Penicillin-insensitive strains of gonococci are prevalent in the Far East, but T. F. Keys and his colleagues $^{5}$ have reported $98 \%$ cure rates in U.S. naval personnel who were given a single injection of 2.4 megaunits of procaine penicillin an hour after $1 \mathrm{~g}$ probenecid by mouth. In this study $73 \%$ of 242 strains of gonococci succumbed to a minimum inhibitory concentration of 0.25 to $1 \mu \mathrm{g}$ penicillin $/ \mathrm{ml}$. These findings show that probenecid has given penicillin a second wind in its race against the adaption of the gonococcus to it.

Many patients prefer pills to needles, though their physicians may prefer the greater certainty to absorption when antibiotics are injected rather than given by mouth. Encouraging results have been obtained by giving ampicillin with probenecid. This also lessens the risk of serious reactions to penicillin and obviates those due to procaine, which can be very alarming. Willcox and his colleagues ${ }^{6}$ gave a single dose of $2 \mathrm{~g}$ ampicillin plus $1 \mathrm{~g}$ probenecid; they had five failures during the first week among 94 men treated in London and 2 among 91 treated in Swansea. Amoxycillin gives higher serum levels than comparable doses of ampicillin. C. D. Alergant ${ }^{7}$ had $12.6 \%$ failures among 136 patients followed up after a single dose of $1 \mathrm{~g}$. When $1 \mathrm{~g}$ probenecid was given as well, the failure rate was reduced to $5.8 \%$ in 136 patients followed up. Only one failure was seen in 95 patients given 1.2 megaunits of procaine penicillin plus $1 \mathrm{~g}$ amoxycillin by mouth.

In previous trials of cotrimoxazole, treatment given over a five-day period has been found effective against the gonococcus. A. S. Wigfield and his colleagues ${ }^{8}$ tried giving six tablets as a single dose, but abandoned this when they had seven failures in 25 patients. The same dose of cotrimoxazole plus a single injection of 1.25 megaunits of Triplopen (benethamine penicillin, procaine penicillin, and benzyl penicillin) gave only three failures in 104 men. They suggest that this combined treatment may be of value in infections due to less sensitive strains of gonococcii. Single doses of 2 to $4 \mathrm{~g}$ of spectinomycin dihydrochloride have been reported to give 90 to $95 \%$ cure rates by B. A. Smithhurst. ${ }^{9}$ L. Z. Oller and his colleagues ${ }^{10}$ gave 50 men a single dose of 400 $\mathrm{mg}$ doxycycline and had only one failure in the 44 who were followed up. This drug has the advantages of rapid absorption and prolonged serum levels, but it produced a high incidence of nausea and vomiting in the patients who took it on an empty stomach. The single failure in treatment was in a patient who vomited 10 minutes after taking it.

These recent reports show that a choice of effective singledose treatments for uncomplicated gonorrhoea is available. Of these, $2 \mathrm{~g}$ ampicillin with $1 \mathrm{~g}$ probenecid or 1.2 to 2.4 megaunits of procaine penicillin plus $2 \mathrm{~g}$ probenecid have ibeen widely used and give acceptable cure rates. But not all patients will be cured, and careful clinical and bacteriological follow-up is essential to detect the small number of failures. It should also be remembered that these antibiotics are not effective against non-specific urethritis. This is becoming increasingly common and is often contracted at the same 
time as gonorrhoea. Because of its longer incubation period, 8 to 14 days, it often presents after gonococcal urethritis has successfully responded to treatment.

1 Willcox, R. R., British Fournal of Venereal Diseases, 1973, 49, 116. 2 Sim, S. K., Canadian Medical Association Fournal, 1972, 107, 986.

${ }^{3}$ Rodin, P., and Seth, A., British fournal of Venereal Diseases, 1972, 48, 517. 4 Cobbold, R. J. C., Spitzer, R. J., Morrison, G. D., and Willcox, R. R., Postgraduate Medical fournal, 1970, 46, 142.

5 Keys, T. F., Halverson, C. W., and Clarke, E. J., fournal of the American Medical Association, 1969, 210, 857.

${ }^{6}$ Willcox, R. R., et al., British fournal of Venereal Diseases, 1973, 49, 263, 268.

'Alergant, C. D., British fournal of Venereal Diseases, 1973, 49, 274

${ }^{8}$ Wigfield, A. S., Selkon, J. B., and Rich, G. E., British fournal of Venereal Diseases, 1973, 49, 277.

${ }^{9}$ Smithurst, B. A., New Zealand Medical fournal, 1972, 75, 82

10 Oller, L. Z., Edwards, J. C., and Lumb, K. M., British fournal of Venereal Diseases, $1973,49,291$.

\section{Preventing Detached Retina}

Treatment to prevent detachment of the retina can be undertaken more effectively if the conditions leading up to it can be identified early. The introduction of the binocular ophthalmoscope has led to a fuller understanding of such lesions.

U. Rutnin and C. L. Schepens ${ }^{1}$ found retinal breaks in $7.8 \%$ of a series of normal eyes, and G. Myer-Schwickerath ${ }^{2}$ assessed the risk of detachment in a group of such patients as $28 \%$. The dangerous type of hole is the large horse-shoe tear, ${ }^{3}$ particularly if it is fresh, ${ }^{4}$ and the least dangerous is the small, flat, peripheral round hole. ${ }^{5}$ The other common precurser of retinal detachment is lattice-like degeneration, ${ }^{6}$ though it is also rather common in eyes which do not develop this complication. ${ }^{7}$ Lattice degeneration is more likely to lead to detachment if retinal holes have developed in the degenerated area, ${ }^{3}$ or if the other eye has suffered a retinal detachment secondary to a lattice tear, or if there is a family history of retinal detachment.

Recently A. H. Chignell and J. Shillings ${ }^{8}$ have reported the results of prophylactic treatment carried out on 202 patients. In their series of high-risk patients retinal detachment occurred after prophylactic treatment in only $5 \%$. The authors used mainly cryotherapy to close the holes, for preference under local anaesthesia. The most serious complication of this method of treatment, apart from later detachment, was puckering of the macula. This occurred in two cases and led to a considerable fall in visual acuity. Thus far this disastrous complication is unpredictable, so that prophylaxis carries with it an element of risk which the patient must recognize and accept before submitting to operation.

The type of retinal detachment carrying the poorest prognosis is that associated with vitreous traction. The vitreous pulls on the retina at several peripheral points and produces either multiple U-shaped tears or sometimes a giant tear involving half or more of the anterior insertion of the retina. In such cases, particularly if the other eye has developed a detached retina, the surgeon should consider creating a per- manent scleral buckle by encircling the globe. J. R. Hudson and colleagues 9 have recently reported on a series of 18 carefully selected high-risk patients of this type in whom the globe was encircled prophylactically. The fellow eye was normal in only one casc of their series, and of the remaining 17 fellow eyes 13 had been previously treated for detachment of the retina and 4 had received prophylactic therapy for retinal breaks. This series of 18 cases has been followed up for 1 to 5 years and only two so far have succumbed to detachment.

Prophylaxis for detached retina is therefore a well-established procedure. It is particularly applicable to myopes who have a family history of retinal separation and to the fellow eye of one which has already developed a retinal separation. Patients in the latter group are unlikely to be overlooked, but the former may learn of the possibility of prophylaxis when it is too late unless their family doctor advises them of it.

\footnotetext{
${ }^{1}$ Rutnin, U., and Schepens, C. L., American fournal of Ophthalmology, 1967 64, 1063 .

Meyer-Schwickerath, G., Transactions of the Canadian Ophthalmological Society, 1963, 26, 9 .

${ }^{3}$ Lincoff, H. A., Archives of Ophthalmology, 1961, 66, 48.

4 Neumann, E., and Hymas, S., British fournal of Ophthalmology, 1972, 56 482 .

5 Cockerham, W. D., and Freeman, H. M., Archives of Ophthalmology, $1968,79,655$

6 Dumas, J., and Schepens, C. L., American fournal of Ophthalmology, $1966,61,620$

Byer, N. E., Transactions of the American Academy of Ophthalmology and Otalaryngology, 1965, 69, 1065.

${ }^{8}$ Chignell, A. H., and Shilling, J., British fournal of Ophthalmology, 1973, $57,291$.

${ }^{9}$ Hudson, J. R., Kanski, J. J., and Elkington, A. R., British fournal of Ophthalmology, 1973, 57, 531.
}

\section{Guernsey Meeting}

The second B.M.A. Annual Postgraduate meeting was held in Guernsey two weeks ago (for a full report of the meeting see p. 97 of this issue). The size of the attendance-some 200 doctors and their wives from all parts of the British Isles, Canada, the United States, and France-and the keen audience participation in all the sessions gave an indication that this kind of gathering meets a real need.

Unique in being one of the oldest attachments to the British crown, in being the only British territory ever enemyoccupied, and in having a private health service, the island and its people aroused the interest and curiosity of the visitors and this was well satisfied by their hosts. The Bailiff of Guernsey, a lawyer whose interest in the medical field is great, figured prominently at the meeting, and the organizers, Dr. M. H. S. Bounds, chairman of the Guernsey and Alderney B.M.A. Division, and Dr. T. W. Parsons, the science secretary, as well as the chairman of the ladies committee, Mrs. C. H. T. Rey, are to be congratulated and thanked for the efficient organization of a pleasurable meeting. 